\title{
ESTIMASI MEDIA ONLINE DALAM PROSES BISNIS PEMASARAN DAN JASA DI KOTA TASIKMALAYA MENGGUNAKAN METODE DISCRETE
}

\author{
Iqbal Dzulfiqar Iskandar \\ Sistem Informasi Kota Tasikmalaya \\ Universitas Bina Sarana Informatika \\ www.bsi.ac.id \\ iqbal.iql@bsi.ac.id
}

\begin{abstract}
Online media is used by many organizations as a helping tool to reach the goal in the business process especially marketing or introducing a product that is marketed. Therefore, this research is trying to explain how massive the role of online media is, in the business process in the town of Tasikmalaya based on a statistic number scale from the data that refer to quantitative methodology, Discrete Data, and Correlational analyses method. Meanwhile. The result of this research reveals Online media is, towards business process marketing and service in the town of the Tasikmalaya area positively affected business process marketing and service. These results are supported by the results of data processing. From 78 organizations, the positive rate of online media on marketing and services is $95 \%$ greater than the positive level, which is only 5\%. sig. (2-sided) of 0,000 , meaning that $\alpha=0.05$ is greater than the value of Sig. (2-sided) or [0.05>0,000]. This shows that the variable $X$ has an influence on variable $Y$. The results of the analysis of bivariate people, obtained the final value $r=1$, for the estimated value. This number defines the variable $X$ which has a very strong attachment relationship to a variable.
\end{abstract}

Intisari- media online dimanfaatkan oleh banyak organisasi, sebagai alat bantu untuk mencapai tujuan dalam proses bisnis, proses memasarkan atau memperkenalkan produk yang akan dipasarkannya. Sehingga pada kesempatan dilakukan penelitian melakukan estimasi terhadap seberapa besar peran media online dalam proses bisnis di wilayah Kota Tasikmalaya, berdasarkan statistik skala angka dari data yang mengacu pada metodologi Kuantitatif, Data descrete serta metode analisis yang digunakan adalah korelasional. Hasil akhir pada penelitian ini menyatakan bahwa peran media online pada proses bisnis pemasaran dan jasa di wilayah Kota Tasikmalaya berpengaruh positif untuk proses bisnis pemasaran dan jasa untuk dimasa mendatang. Hasil tersebut di dukung oleh hasil pengolahan data Dari 78 Organisasi menyatakan tingkat pengaruh positif media online terhadap pemasaran dan jasa lebih besar 95\% daripada tingkat pengaruh positif, yang hanya $5 \%$. sig.(2-sided) sebesar 0,000, ternyata $\alpha=0,05$ lebih besar dari nilai Sig.(2-sided) atau $[0,05>0,000]$. Hal ini menunjukan bahwa variabel $X$ memiliki pengaruh terhadap variabel $Y$. Hasil analisis Bivariate person, didapatkan nilai akhir $\mathrm{r}=1$, untuk nilai estimasinya. Angka tersebut mengartikan variabel $\mathrm{X}$ memiliki hubungan keterikatan yang sangat kuat terhadap variabel Y. Sehingga dapat disimpulkan bahwa media online memiliki hubungan yang kuat terhadap proses bisnis.

Kata Kunci: Discrete, Estimasi, Korelasional, Proses Bisnis, Tasikmalaya,

\section{PENDAHULUAN}

Tasikmalaya merupakan kota yang terletak di provinsi jawabarat yang memimiliki potensi perkembangan perekonomian yang berkembang sangat pesat dan positif, seperti diantaranya banyak masyarakat membuka usaha berupa usaha kecil, menengah, dan atas, baik itu usaha swasta maupun kepemerintahan(Pemerintah Kota Tasikmalaya, 2018) data hasil studi literatur menunjukkan peningkatan yang signifikan pada bidang komunikasi dan informasi yang memiliki pertumbuhan $13,25 \%$, lalu pada kesehatan dan sosial menjadi kegiatan yang tumbuh 12,42\%, kategori jasa Pendidikan tumbuh sebesar 10,60\% serta kategori kontruksi tumbuh 10,03\%. (Ratih Purbasari, Chandra Wijaya, Ning Rahayu, 2018) Dalam pengembangan usaha terdapat Media online yang di manfaatkan oleh organisasi atau perusahaan, sebagai alat bantu untuk mencapai tujuan dalam proses bisnis (Basri \& Eko Indrajit, 2017), khususnya dalam proses memasarkan atau memperkenalkan produk yang akan dipasarkannya. Hal tersebut menjadi acuan dalam Pemasaran internet, yang mengharuskan adanya kreatifitas beserta memiliki keterampilan teknis. Media online secara bersama-sama, mencakup periklanan dan penjualan yang menyangkut berbagai cara untuk meraih keberhasilan dalam proses bisnis.(Emzir, 2015) pada kesempatan ini telah dilakukan penelitian yang menegaskan seberapa besar peran media online dalam proses 
bisnis di wilayah Kota Tasikmalaya, berdasarkan statistik skala angka dari data yang mengacu pada metodologi Kuantitatif bertipe korelasional serta data Discrete (Siaga, Januar, \& Kusmiati, 2016)

Sebagai perbandingan terdapat beberapa penelitian yang terkait dengan riset ini seperti penelitian yang dilakuukan oleh (Priambada, 2017) melakukan riset berkaitan dengan UKM dari data hasil penelitian yang telah dilakukan sebanyak 97 $\%$ pelaku usaha UKM menggunakan media sosial untuk melakukan promosi usaha, penelitian yang dilakukan (Pramono, 2018) meng implementasi augmented reality berbasis web untuk aplikasi furniture shopping manager yang bertujuan sebagai alat bantu belanja online, riset tersebut mengimplementasikan augmented reality untuk dijadikan media online berupa website yang bertujuan untuk menarik dan mempermudah pelanggan dalam meningkatkan bisnis penjualan, penelitian oleh (Susanti, Hadi, \& Si, 2013) menganalisa kepercayaan konsumen dalam melakukan pembelian Gadget secara Online kepada 5 subjek yang pernah melakukan belanja online dan kepada two significant other sebagai peran penjual gadget online, dengan gambaran kepercayaan konsumen melalui process based trust, institution based trust, ability, benevolence, integrity, menyimpulkan kepuasan setelah pembelian, dapat menibulkan kecenderungan pelanggan untuk membeli ulang secara online meskipun dengan prilaku konsumen yang berbedabeda.

Proses bisnis menggunakan media online sangat populer dikembangkan oleh masyarakat dan lingkungan akademisi dan menjadi sebuah kerangka kebutuhan informasi dalam pengolahan produksi komoditi(Suprihadi, Tanone, \& Suharyadi, 2016)(Helmi, Aknuranda, \& Saputra, 2018), selain itu pengelolaan media online paada proses bisnis sangat penting, untuk meningkatkan omset bisnis itu senditi seperti riset yang dilakukan dengan judul penggunaan media online untuk bisnis oleh perempuan menyatakan pengelolaan media online dalam menyampaikan deskripsi informasi harus baik dan akurat karena berpengaruh terhadap pendapatan. Dari beberapa penelitian yang telah diuraikan terkait dengan media online proses bisnis telah memberikan data hasil riset sebagai gambaran yang relevan atas besarnya potensi keuntungan dalam memadukan proses bisnis dengan media online. Tetapi dalam penelitian-penelitian tersebut terdapat kekurangan yaitu, melakukan riset dalam satu objek penelitian saja. Maka akan dibahas penelitian dengan cakupan objek penelitian yang lebih banyak dan luas dengan judul "Estimasi Media Online Dalam Proses Bisnis Pemasaran Dan Jasa Mengunakan Metode Discrete". Menggunakan pendekatan data mining, sehingga dapat diketahui seberapa besar peran media online pada proses bisnis saat ini. Beberapa hal yang menjadi batasan dan dasar dalam penelitian ini adalah data yang digunakan menggunakan data discrete yang memiliki dua sekala 1 (Ya) dan 0 (Tidak) (Sugianto, 2016) sumber data yang diambil dari data penggunaan media online yang telah di tentukan menggunakan teknik purposive sampling yang dilakukan di wilayah Kota Tasikmalaya dengan jumlah objek penelitian yang didapatkan sebanyak 78 Organisasi atau perusahaan. sedangkan tools yang di pergunakan dalam pengolahan data penelitian menggunakan SPS-S. Tujuan yang ingin dicapai dalam penelitian ini adalah untuk melakukan analisa peran media online pada proses bisnis serta mengetahui estimasi seberapa besar peran media online pada proses bisnis saat ini. Memberikan informasi tingkat kepercayaan dalam memanfaatkan media online sebagai alat pendukung dalam proses bisnis.

\section{BAHAN DAN METODE}

Alur metode penelitian "Estimasi Media Online Dalam Proses Bisnis Pemasaran Dan Jasa mengikuti framework yang di usulkan yang di tampilkan pada gambar 1 .

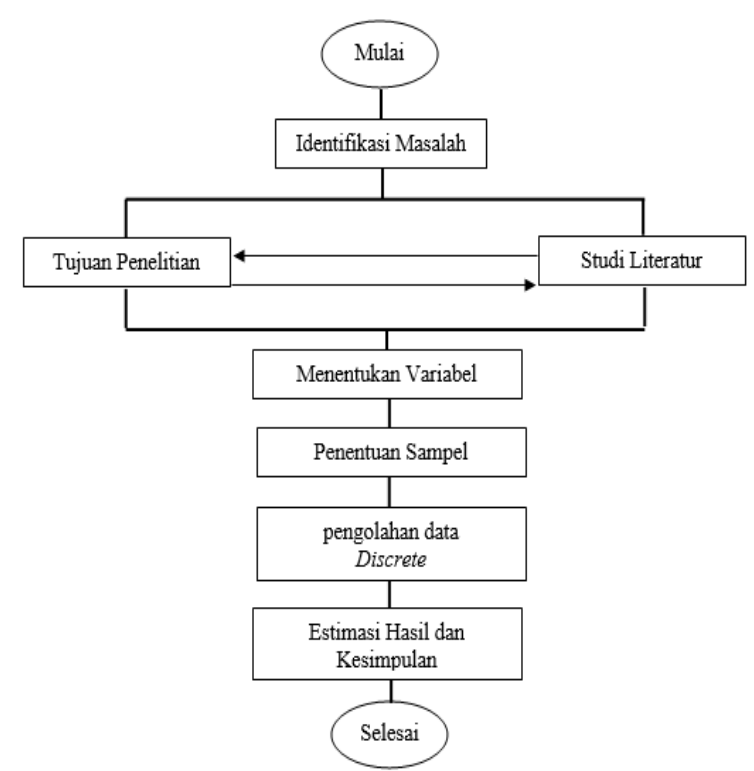

Sumber: (Iskandar, 2019)

Gambar1. Framework Estimasi Media Online

Dalam Proses Bisnis Pemasaran Dan Jasa yang di usulkan

Gambar1 adalah framework yang diusulkan dalam proses penelitian estimasi media online pada proses bisnis, terdiri dari tahapan identifikasi masalah, menentukan tujuan penelitian, studi literatur, menentukan variable, penentuan sampel, 
pengolahan data discrete, lalu dilakukan estimasi sehingga dapat diambil kesimpulan. Alur proses dari framework akan di jelaskan sebagai berikut:

\section{1) Identifikasi Masalah}

Proses bisnis sangat berperan aktif sebagai proses dalam mencapai misi dan visi dalam organisasi atau perusahaan. Di balik berjalannya proses bisnis, terdapat media yang digunakan sebagai penggerak untuk menetukan masadeapan proses bisnis tersebut, salahsatu diantaranya adalah media online. Berkaitan dengan hal itu dalam penelitian ini, akan menegaskan seberapa besar peran media online dalam proses bisnis. Penelitian difokuskan pada peran media online yang dipergunakan untuk sub proses bisnis, yaitu proses pemasaran atau jasa yang dihasilkan oleh organisasi atau perusahaan.

\section{2) Tujuan}

Tujuan dari penelitian ini adalah melakukan Estimasi Peran Media Online Dalam Proses Bisnis Pemasaran Dan Jasa serta mengetahui informasi seberapa besar peran media online pada proses bisnis berdasarkan statistik skala angka melalui pendekatan data mining.

\section{3) Studi Literatur}

Studiletarur merupakan pengkajian terhadap permasalahan secara kronologis, dari semenjak permasalahan tersebut mulai ditemukan sampai pada keadaan yang kini terlihat, yang memberikan dasar teoriti yang lebih jelas terkait riset ini, dengan ditunjangnya referensi yang terkait dengan permasalahan yang ditemukan. Maka referensi tersebut berisikan : Perkembangan Media online, Proses Bisnis, Pemasaran Internet, Metodologi penelitian

Referensi ini dapat dicari dari buku, jurnal, serta artikel laporan penelitian. Hasil luaran dari studi literatur ini adalah menemukan referensi yang relevan dengan perumusan masalah. Tujuannya adalah untuk memperkuat permasalahan serta perbandingan sebagai dasar teori dalam melakukan penelitian peran media online pada proses bisnis

\section{4) Menentukan Variabel Penelitian}

Variabel yang akan ditentukan pada riset ini berjumlah dua variable independent dan dependen. Maka dapat ditentukan bahwa media online sebagai variabel independent $(\mathrm{X})$, karena media online mempengaruhi proses bisnis. Sedangkan proses bisnis Merupakan variabel dependent, karena dipengaruhi oleh media online $(\mathrm{Y})$.

$\mathrm{Y}=$ Proses Bisnis
$\mathrm{X}=$ Media online

\section{5) Penentuan Sampel}

Sampel merupakan objek penelitian yang mewakili populasi sebenarnya. Untuk menentukan populasi dengan Teknik purposive. Maka mengacu pada rumus berikut Langkah-langkah Purposive Sampling (Palinkas et al., 2015), untuk menerapkan teknik purposive samplingadalah sebagai berikut : menentukan tujuan dari penelitian serta kriteria tertentu pada sampel agar tidak terjadi bias. Setelah itu menentukan kriteriakriteria dari instrument riset, Tentukan populasi berdasarkan studi pendahuluan yang teliti. Tentukan jumlah minimal sampel yang akan dijadikan subjek penelitian serta memenuhi kriteria dengan metode cohort (Alfadin, Hidayat, Arifin, \& Kusumaningrum, 2018) sehingga dapat ditentukan kriteria untuk sampel dalam penelitian ini yang mengacu pada metode nonprobabily purposive adalah sebagai berikut: Perusahaan atau organisasi tetap, Perusahaan yang memiliki koneksi internet dan bidang usaha, Perusahaan yang memanfaatkan media online pada proses bisnis, Perusahaan yang memanfaatkan media online untuk menawarkan barang atau jasa, Perusahaan yang memanfaatkan media online untuk media pemasaran, Perusahaan yang memanfaatkan internet untuk media promosi. Dari kriteria tersebut di dapatkan 78 Organisasi atau Perusahaan di Kota Tasikmalaya dengan jumlah keseluruhan responden 100 untuk dijadikan sampel penelitian.

\section{Uji hipotesa}

One sample t-test (uji satu sampel dengan ttest) merupakan salah satu analisis untuk membandingkan rata-rata dari dua populasi atau lebih. Uji termasuk dalam Compare Mean. Uji ini juga merupakan statistik yang bisa digunakan untuk membandingkan rata-rata sampel yang diuji dengan rata-rata populasi yang sudah ada. (Sari, 2017) Kaidah keputusan untuk uji normalitas yang akan di implementasikan pada data penggunaan media online :

Jika $\alpha=0,05$ lebih kecil atau sama dengan nilai Sig.(2-Sided) atau $[\alpha=0,05 \leq$ Sig (2-Sided). Maka Ho diterima dan Ha ditolak. Jika $\alpha=0,05$ lebih besar atau sama dengan nilai Sig.(2-Sided) atau $[\alpha$ $=0,05 \geq \operatorname{Sig}$ (2-Sided). Maka Ha diterima dan Ho ditolak.(Riduwan \& Sunarto, 2014)

\section{Uji Normalitas}

Tujuan uji normalitas adalah untuk mengetahui apakah distribusi sebuah data mengikuti atau mendekati distribusi normal, yakni distribusi data yang mampunyai pola seperti distribusi normal. Uji normalitas mengacu pada metode uji Kolmogorov Smirnov. Kolmogorov 
Smirnov merupakan uji beda pada normalitas masing-masing data berdasarkan data normal baku, berarti jika nilai signifikansi kurang dari 0,05 . Maka terdapat perbedaan yang signifikan, jika angka signifikasn lebih dari sama dengan 0,05 maka tidak terjadi perbedaan yang signifikan. Penerapan metode uji Kolmogorov Smirnov menyatakan apabila nilai kurang dari 0,05 artinya data yang akan diuji memiliki perbedaan yang signifikan dengan data normal baku data tersebut dikategorikan tidak normal. Tetapi jika nilai lebih besar dari 0,05. berarti data uji tersebut tidak berbeda jauh antara data yang akan diuji dengan data normal, artinya data yang di uji termasuk kedalam data yang bersifat normal, karena tidak memiliki perbedaan dengan data normal.

\section{Korelasi Sederhana}

Bivariate Correlation bertujuan untuk mengetahui tingkat korelasi antara dua variabel dengan indikator nilai korelasi sehingga tingkat korelasi dapat diukur. Nilai korelasi (r) berkisar antara 1 sampai -1 , nilai semakin mendekati 1 atau -1 berarti hubungan antara dua variabel semakin kuat, sebaliknya nilai mendekati 0 artinya korelasi dua variabel akan semakin lemah. Nilai positif menunjukkan hubungan searah (X naik maka Y naik) dan nilai negatif menunjukkan hubungan terbalik (X naik maka $Y$ turun) (Nugroho, Akbar, \& Vusvitasari, 2008) Acuan untuk tingkat nilai koefisien korelasi dijasikan pada table 1 .

Tabel1. Makna Nilai Korelasi Bivariate

\begin{tabular}{cc}
\hline Nilai & Makna \\
\hline $0,00-0,199$ & Tidak Berpengaruh \\
\hline $0,20-0,599$ & Berpengaruh \\
\hline $0,600-0,1000$ & Sangat Berpengaruh \\
\hline
\end{tabular}

Sumber: (Nugroho et al., 2008)

Keputusan pada korelasi Bivariate ditentukan dengan 3 cara.

Tabel 2. Tiga keputusann Korelasi Bivariate

\begin{tabular}{|c|c|}
\hline Nilai & Makna \\
\hline \multicolumn{2}{|c|}{ Cara Pertama } \\
\hline $\begin{array}{c}\text { Jika Sig. }(2 \text {-tailed })< \\
0,05\end{array}$ & $\begin{array}{c}\text { Terdapat korelasi pada } \\
\text { variable yang dihubungkan }\end{array}$ \\
\hline $\begin{array}{l}\text { Jika Sig.(2-tailed) } \\
\quad>0,05\end{array}$ & $\begin{array}{l}\text { Tidak Terdapat korelasi } \\
\text { pada variable yang } \\
\text { dihubungkan }\end{array}$ \\
\hline \multicolumn{2}{|c|}{ Cara Kedua } \\
\hline $\begin{array}{c}\text { Jika nilai } r \text { hitung }> \\
r \text { tabel }\end{array}$ & $\begin{array}{l}\text { Terdapat korelasi antar } \\
\text { variabel }\end{array}$ \\
\hline $\begin{array}{c}\text { Jika nilai } r \text { hitung }< \\
r \text { tabel }\end{array}$ & $\begin{array}{l}\text { Terdapat korelasi antar } \\
\text { variabel }\end{array}$ \\
\hline \multicolumn{2}{|c|}{$\begin{array}{c}\text { Cara ke Tiga berdasarkan tanda bintang yang } \\
\text { diberikan SPSS }\end{array}$} \\
\hline (*) pada nilai & Terjadi Korelasi antar \\
\hline
\end{tabular}

\begin{tabular}{cc}
\hline pearson correlation & variabel \\
\hline$\left.{ }^{* *}\right)$ pada nilai & Terjadi Korelasi antar \\
pearson correlation & variabel \\
\hline$(-)$ tidak ada & Tidak terjadi Korelasi antar \\
bintang & variabel \\
\hline
\end{tabular}

Sumber: (Setyawarno, 2016)

"Tanda bintang satu $\left(^{*}\right)$ mengartikan korelasi pada signifikansi $1 \%$ atau 0,01 , sedaangkan tanda bintang dua $\left({ }^{* *}\right)$ menunjukan korelasi pada signifikansi $5 \%$ atau $0,05 "$.

\section{Koefisien Determinasi}

Metode Koefisien determinasi dipergunakan untuk mengetahui besarnya pengaruh variabel independent $(\mathrm{X})$ terhadap variabel dependent $(\mathrm{Y})$. Adapun perhitungannya menggunakan rumus berikut

$\mathrm{KD}=\mathrm{r}^{2} \times 100$

Keterangan :

KD = Koefisien Determinasi.

$\mathrm{r}^{2} \quad=$ Koefisien Determinasi

$100=$ Bilangan tetap

\section{HASIL DAN PEMBAHASAN}

Jumlah responden terdiri 100 responden yang diambil dari 78 Organisasi atau perusahaan, yang ditentukan berdasarkan metode penentuan sample nonprobabily berupa teknik purposive sampling. Setelah proses pengambilan sampel. Maka dilakukan proses pengolahan data pengguna media online untuk proses bisnis pada setiap organisasi, perusahaan dan Lembaga pemerintahan.

\section{Uji Hipotesis Terhadap Data}

Tabel 3. One-sample Statistics Uji Hipotesis terhadap data media online

\begin{tabular}{lcccc}
\hline & $\mathrm{N}$ & Mean & Std. Deviation & $\begin{array}{c}\text { Std. Error } \\
\text { Mean }\end{array}$ \\
\hline $\begin{array}{l}\text { Media } \\
\text { Online }\end{array}$ & 100 & 6.24E5 & 329272.293 & 32927.224 \\
\hline
\end{tabular}

Sumber: (Iskandar, 2019)

Tabel 4. Hasil Uji Hipotesis One-sample Test terhadap data media online Test Value $=21$

95\% Confidence Interval of the Difference

\begin{tabular}{|c|c|c|c|c|c|c|}
\hline & $t$ & $d f$ & $\begin{array}{l}\text { Sig. } \\
(2- \\
\text { taile } \\
\text { d) }\end{array}$ & $\begin{array}{c}\text { Mean } \\
\text { Differenc } \\
e\end{array}$ & Lower & Upper \\
\hline $\begin{array}{c}\text { Medi } \\
\text { a } \\
\text { Onli } \\
\text { ne }\end{array}$ & $\begin{array}{c}18.9 \\
36\end{array}$ & $\begin{array}{l}9 \\
9\end{array}$ & 000 & $\begin{array}{c}623518.3 \\
60\end{array}$ & $\begin{array}{c}558183 . \\
60\end{array}$ & $\begin{array}{c}688853 . \\
12\end{array}$ \\
\hline
\end{tabular}

Sumber: (Iskandar, 2019) 
Berdasarkan hasil analisis tool SPSS sig.(2-sided) sebesar 0,000, ternyata $\alpha=0,05$ lebih besar dari nilai Sig.(2-sided) atau [0,05 > 0,000]. Maka Ha diterima dan Ho ditolak. Artinya Media online mempengaruhi proses bisnis.

\section{Analisis Korelasi Bivariate Person}

Analisis Korelasi Bivariate person, digunakan untuk mengukur hubungan dengan data terdistribusi normal. Berikut dibawah ini merupakan hasil analisis menggunakan SPSS, keterhubungan antara variabel $\mathrm{X}=$ media online devendent yang mempengaruhi, dengan variabel $\mathrm{Y}=$ proses bisnis indevendent yang dipengaruhi.

Tabel 5. Analisis Korelasi Bivariate person

\begin{tabular}{|c|c|c|c|c|c|}
\hline No & Variabel & Variabel & $\begin{array}{c}\text { Data } \\
\text { Media } \\
\text { online } \\
\text { dari } \\
\text { objek } \\
\text { riset }\end{array}$ & $\begin{array}{l}\text { Nilai } \\
\text { Pearson } \\
\text { Corellation } \\
\text { (r) }\end{array}$ & $\begin{array}{c}\text { Makna } \\
\text { Hubungan }\end{array}$ \\
\hline 1 & $\mathrm{X}$ & $\mathrm{Y}$ & 76 & 0.355 & Berpengaruh \\
\hline 3 & $\mathrm{X}$ & $\mathrm{Y}$ & 76 & 0,212 & Berpengaruh \\
\hline 4 & $\mathrm{X}$ & $\mathrm{Y}$ & 54 & 0,389 & Berpengaruh \\
\hline 5 & $\mathrm{X}$ & $\mathrm{Y}$ & 50 & 0.493 & Berpengaruh \\
\hline 6 & $\mathrm{X}$ & $\mathrm{Y}$ & 67 & 0.529 & Berpengaruh \\
\hline 9 & $\mathrm{X}$ & $\mathrm{Y}$ & 71 & 0.495 & Berpengaruh \\
\hline 10 & $\mathrm{X}$ & $\mathrm{Y}$ & 69 & 0.455 & Berpengaruh \\
\hline 12 & $\mathrm{X}$ & $\mathrm{Y}$ & 74 & 225 & Berpengaruh \\
\hline 13 & $\mathrm{X}$ & $\mathrm{Y}$ & 76 & 0.319 & Berpengaruh \\
\hline 14 & $\mathrm{X}$ & $\mathrm{Y}$ & 67 & 0.300 & Berpengaruh \\
\hline 15 & $\mathrm{X}$ & $\mathrm{Y}$ & 77 & 0.212 & Berpengaruh \\
\hline 16 & $\mathrm{X}$ & $\mathrm{Y}$ & 76 & 0.200 & Berpengaruh \\
\hline 17 & $\mathrm{X}$ & $\mathrm{Y}$ & 15 & 0.179 & Berpengaruh \\
\hline 18 & $\mathrm{X}$ & $\mathrm{Y}$ & 44 & 0.378 & Berpengaruh \\
\hline 19 & $\mathrm{X}$ & $\mathrm{Y}$ & 32 & 0.363 & Berpengaruh \\
\hline 20 & $\mathrm{X}$ & $\mathrm{Y}$ & 56 & 0.479 & Berpengaruh \\
\hline 21 & $\mathrm{X}$ & $\mathrm{Y}$ & 72 & 0.692 & $\begin{array}{l}\text { Sangat } \\
\text { Berpengaruh }\end{array}$ \\
\hline & \multicolumn{2}{|l|}{ Jumlah } & 1092 & 1 & $\begin{array}{l}\text { Sangat } \\
\text { Berpengaruh }\end{array}$ \\
\hline \multicolumn{6}{|c|}{ PENGARUH NEGATIF } \\
\hline 2 & $\mathrm{X}$ & $\mathrm{Y}$ & 5 & $-0,79$ & $\begin{array}{l}\text { Tidak } \\
\text { berpengaruh }\end{array}$ \\
\hline 7 & $\mathrm{X}$ & $\mathrm{Y}$ & 9 & 0.21 & $\begin{array}{l}\text { Sedikit } \\
\text { berpengaruh }\end{array}$ \\
\hline 8 & $\mathrm{X}$ & $\mathrm{Y}$ & 13 & $-0,76$ & $\begin{array}{l}\text { Tidak } \\
\text { berpengaruh }\end{array}$ \\
\hline 11 & $\mathrm{X}$ & $\mathrm{Y}$ & 13 & -0.35 & $\begin{array}{l}\text { Tidak } \\
\text { berpengaruh }\end{array}$ \\
\hline
\end{tabular}

Sumber: (Iskandar, 2019)

Dari hasil analisis Bivariate person, didapatkan nilai akhir $r=1$, angka tersebut mengartikan bahwa variabel $\mathrm{X}$ memiliki pengaruh keterikatan yang sangat kuat terhadap variabel Y.

Dari hasil analisis Bivariate person, didapatkan nilai akhir $r=1$, angka tersebut mengartikan bahwa variabel $\mathrm{X}$ memiliki pengaruh keterikatan yang sangat kuat terhadap variabel Y.

\section{Koefisien Determinasi}

Metode Koefisien determinasi dipergunakan untuk mengetahui besarnya pengaruh variabel independent $(\mathrm{X})$ terhadap variabel dependent $(\mathrm{Y})$.

$$
\begin{aligned}
\mathrm{KD} & =12 \times 100 \% \\
& =100
\end{aligned}
$$

Berdasarkan hasil perhitungan koefisien determinasi diatas, menunjukan bahwa pengaruh variabel $(\mathrm{X})$ media online Terhadap variabel (Y) Proses Bisnis adalah 100\%

\section{KESIMPULAN}

Berdasarkan hasil pengumpulan dan pengolahan data dalam penelitian ini. Maka dapat disimpulkan bahwa variabel $\mathrm{X}=$ Media Online memiliki peran sangat penting serta mempengaruhi variabel $\mathrm{Y}=$ Proses Bisnis. Hasil tersebut di dukung oleh hasil pengolahan data Dari 78 Organisasi dengan 100 responden menyatakan tingkat pengaruh positif media online terhadap pemasaran dan jasa lebih besar 95\% daripada tingkat pengaruh positif, yang hanya $5 \%$. Berdasarkan hasil analisis hipotesis dengan metode one sample test sig.(2-sided) sebesar 0,000 , ternyata $\alpha=0,05$ lebih besar dari nilai Sig.(2sided) atau $[0,05>0,000]$. Hal ini menunjukan bahwa variabel $X$ memiliki pengaruh terhadap variabel Y. Sehingga Media Online berpengaruh pada proses bisnis pemasaran dan jasa. Hasil analisis Bivariate person, didapatkan nilai akhir $r=$ 1, untuk nilai estimasinya. Angka tersebut mengartikan variabel $\mathrm{X}$ memiliki hubungan keterikatan yang sangat kuat terhadap variabel Y. Sehingga dapat disimpulkan bahwa media online memiliki hubungan yang kuat terhadap proses bisnis. Berdasarkan data hasil akhir pengolahan yang telah di uraikan. Maka dapat ditarik kesimpulan akhir dari penelitian ini, bahwa media online di Kota Tasikmalaya sangat berperan besar untuk keberlangsungan hidup dan kesuksesan proses bisnis di masa mendatang.

Saran untuk melengkapi kekurangan dari riset ini adalah tidak melibatkannya sub variabel pada berbagai jenis media online, yang artinya hanya terdapat dua variabel utama, yaitu Variabel $\mathrm{X}=$ Media online dan Y = Proses Bisnis. Serta wilayah penelitian dapat di kembangkan sampai tingkat Provinsi Jawabarat.

\section{REFERENS}

Alfadin, M. R., Hidayat, T., Arifin, M. Z., \& Kusumaningrum, R. (2018). Kajian pemilihan antara taksi berbasis aplikasi online dan taksi konvensional kasus kota surabaya. Journal Mahasiswa Teknik Sipil, 1(2), 1-10. Retrieved from

http://sipil.studentjournal.ub.ac.id/index.ph p/jmts/article/view/728

Basri, H., \& Eko Indrajit, R. (2017). Implementasi Information Retrivals Untuk Meningkatkan Pemasaran Produk. Jurnal Pilar Nusa Mandiri, 
13(2), 249-254.

Emzir. (2015). Metodologi Penelitian Kuantitatif dan Kualitatif untuk Pendidikan (1st ed.). Depok: Rajawali Pers.

Helmi, A. T., Aknuranda, I., \& Saputra, M. C. (2018). Analisis Dan Pemodelan Proses Bisnis Menggunakan Business Process Improvement (BPI) Pada Lembaga Bimbingan Belajar (Studi Kasus: Lembaga Bimbingan Belajar Prisma). Jurnal Pengembangan Teknologi Informasi Dan Ilmu Komputer (J-PTIIK) Universitas Brawijaya, $2(10)$.

Iskandar, I. D. (2019). Laporan Akhir Penelitian: Estimasi Media Online Dalam Proses Bisnis Pemasaran Dan Jasa Di Kota Tasikmalaya Menggunakan Metode Discrete. Tasikmalaya.

Nugroho, S., Akbar, S., \& Vusvitasari, R. (2008). Kajian Hubungan Koefisien Korelasi Pearson (r), Spearman-rho (?), Kendall-Tau (?), Gamma (G) , dan Somers. GRADIEN : Jurnal Ilmiah MIPA, 4(2), 372-381. Retrieved from https://ejournal.unib.ac.id/index.php/gradie n/article/view/279

Palinkas, L. A., Horwitz, S. M., Green, C. A., Wisdom, J. P., Duan, N., \& Hoagwood, K. (2015). Purposeful Sampling for Qualitative Data Collection and Analysis in Mixed Method Implementation Research. Administration and Policy in Mental Health and Mental Health Services Research, 42(5), 533-544. https://doi.org/10.1007/s10488-013-0528-y

Pemerintah Kota Tasikmalaya. (2018). Kondisi ekonomi kota tasikmalaya. Tasikmalaya: Pemerintah Kota Tasikmalaya.

Pramono, B. A. (2018). Desain Dan Implementasi Augmented Reality Berbasis Web Pada Aplikasi Furniture Shopping Manager Sebagai Alat Bantu Belanja Online. Jurnal Transformatika, $\quad 10(1), \quad 26$. https://doi.org/10.26623/transformatika.v1 $0 \mathrm{i} 1.67$

Priambada, S. (2017). Potensi Media Sosial Bagi Usaha Kecil Dan Menengah (UKM) di Malang Raya. Seminar Nasional Sistem Informasi Indonesia, (November), 1-8.
Ratih Purbasari, Chandra Wijaya, Ning Rahayu, E. M. (2018). CREATIVE INDUSTRY MAPPING IN EAST PRIANGAN REGION: IDENTIFYING OF LOCAL COMPETITIVE ADVANTAGE. Jurnal Pemikiran Dan Penelitian Administrasi Bisnis Dan Kewirausahaan, 3(1), 1-11. https://doi.org/https://doi.org/10.24198/ad bispreneur.v3i1.16083

Riduwan, R., \& Sunarto, H. (2014). Pengantar Statistika Pendidikan, Sosial, Ekonomi, Komunikasi, dan Bisnis. Bandung: Alfabeta.

Sari, R. A. (2017). Pengaruh Karakteristik Perusahaan, Disclosure, Terhadap Corporate Social Responsibility Manufaktur, Pada Perusahaan Yang Terdaftar Di Bursa Efek Indonesia. Jurnal Nominal, I(I), 124-140.

Setyawarno, D. (2016). Panduan statistik terapan untuk penelitian pendidikan. In PANDUAN STATISTIK TERAPAN UNTUK PENELITIAN PENDIDIKAN (pp. 1-116). Yogyakarta: Universitas Negri Yogyakarta.

Siaga, Y. S., Januar, J., \& Kusmiati, A. (2016). Penerapan dan Pemanfaatan Media Online dalam Pengembangan Sistem Pemasaran UMKM ( Agroindustri ) di Kabupaten Jember, (1), 433-441.

Sugianto, A. (2016). Jenis-Jenis Data Variabel (Variabel Diskrit dan Variabel Kontinyu). Researchgate, (August), 1-5.

Suprihadi, S., Tanone, R., \& Suharyadi, S. (2016). Proses Bisnis E-Catalogue Baru Sebagai Kerangka Kebutuhan Informasi Pengolahan Produksi Komoditi. In Prosiding Konser Karya Ilmiah Nasional 2016 (pp. 243-254). Salatiga: Fakultas Pertanian dan Bisnis Universitas Kristen Satya Wacana.

Susanti, V., Hadi, C., \& Si, M. (2013). Kepercayaan Konsumen dalam Melakukan Pembelian Gadget secara Online. Psikologi Industri Dan Organisasi, 02(01), 55-33. 